\title{
Changes in Phospholipid Composition of Erythrocyte Membrane in Alzheimer's Disease
}

\author{
Shinji Oma ${ }^{a}$ Shiro Mawatari ${ }^{b}$ Kazuyuki Saito $^{c}$ Chikako Wakana ${ }^{c}$ \\ Yoshio Tsuboi $^{a}$ Tatsuo Yamada ${ }^{a}$ Takehiko Fujino ${ }^{b, c}$ \\ ${ }^{a}$ Department of Neurology, Fukuoka University School of Medicine, ${ }^{b}$ Institute of Rheological \\ Function of Food, and 'Boocs Clinic Fukuoka, Fukuoka, Japan
}

\section{Key Words}

Alzheimer's disease • Erythrocyte phospholipids - Ethanolamine plasmalogen •

Sphingomyelin $\cdot$ Oxidative stress

\begin{abstract}
Background: There are several reports indicating a decrease of ethanolamine plasmalogen (pl$P E$ ) in brain tissues and in serum of patients with Alzheimer's disease (AD). The present study aimed to examine the composition of erythrocyte phospholipids including pl-PE in patients with AD. Method: A high-performance liquid chromatography (HPLC) method that can separate intact plasmalogens and all other phospholipid classes by a single chromatographic run was used. Results: The ratios of pl-PE, phosphatidylethanolamine (PE) and phosphatidylserine (PS) to sphingomyelin were low as compared to those of the age-matched controls. Conclusion: These changes in erythrocyte phospholipids may reflect changes induced by oxidative stress, indicating the presence of high oxidative stress in the peripheral blood of AD patients.
\end{abstract}

Copyright $\odot 2012$ S. Karger AG, Basel

\section{Introduction}

Alzheimer's disease (AD) is the most common cause of dementia in the elderly. As life expectancy increases, AD is becoming a major health problem worldwide. Several reports indicate the decrease of ethanolamine plasmalogen (pl-PE) in the brain tissues of AD patients [1-3]. It was also reported that pl-PE decreased in the serum of $\mathrm{AD}$ patients and that 
Table 1. Age, gender, and MMSE score of subjects

Oma et al.: Changes in Phospholipid Composition of Erythrocyte Membrane in Alzheimer's Disease

\begin{tabular}{lcc}
\hline & Control $(\mathrm{n}=15)$ & $\mathrm{AD}(\mathrm{n}=16)$ \\
\hline Age, years & $73.1 \pm 4.6$ & $76.5 \pm 8.1$ \\
Sex, m/f & $5 / 10$ & $7 / 9$ \\
MMSE score & $30.0 \pm 0$ & $4.1 \pm 3.4$ \\
\hline
\end{tabular}

the decrease of pl-PE in the serum correlated with severity of dementia $[4,5]$. Plasmalogens in animals are primarily present in the cell membrane of tissues, hence, blood cells in the peripheral blood contain a much higher amount of pl-PE than serum. We previously reported on high-performance liquid chromatography (HPLC) which can separate intact plasmalogens and all other phospholipids by a single run [6]. The HPLC method detects only traces of pl-PE of human serum, but the method clearly detects pl-PE of the human erythrocyte [6]. Several abnormalities in the erythrocytes from patients with AD have been reported [7-11], but a possible abnormality of erythrocyte pl-PE has not been tested hitherto. In the present study, we measured phospholipid composition including pl-PE of erythrocytes from patients with AD compared to age-matched control subjects.

\section{Subjects and Methods}

\section{Subjects}

Sixteen subjects with AD and 15 age-matched normal control subjects were enrolled at the Department of Neurology, Fukuoka University Hospital, Fukuoka, Japan. The study was conducted according to the Declaration of Helsinki and was approved by the Institutional Review Board of Fukuoka University Hospital. AD was diagnosed clinically including MiniMental State Examination (MMSE) score. Subjects with a high ratio $(>2)$ of low-density lipoprotein to high-density lipoprotein, obesity, hypertension, and high blood sugar levels were excluded from the control group, and subjects with high C-reactive protein $(>1 \mathrm{mg} / 100$ $\mathrm{ml}$ ) were excluded from either group. Age, gender, and MMSE score are reported in table 1. Serum total cholesterol, low-density lipoprotein, high-density lipoprotein, triglyceride, blood sugar levels, and C-reactive protein in AD patients were statistically not different from the control group.

\section{Preparation of Erythrocytes}

Venous blood of the subjects who had fasted overnight was drawn into tubes containing EDTA-2Na. The blood was cooled in an ice bath and was kept in a refrigerator, and it was processed within $48 \mathrm{~h}$. Plasma and buffy coat were removed after centrifugation at $1,000 \mathrm{~g}$ for $5 \mathrm{~min}$ at $4^{\circ} \mathrm{C}$, and the erythrocytes were washed three times in cold isotonic saline at $1,000 \mathrm{~g}$ for $5 \mathrm{~min}$ at $4^{\circ} \mathrm{C}$. A small portion of the top layer was removed at each washing.

\section{Determination of Lipid Composition of Erythrocytes}

Extraction of lipids from erythrocytes was essentially performed according to the method reported by Mawatari et al. [6] and Dise et al. [12]. Briefly, $500 \mu l$ of the packed erythrocytes was hemolyzed with an equal volume of $10 \mathrm{mM}$ phosphate buffer ( $\mathrm{pH}$ 7.4). Four milliliter of methanol was added to the lysate followed after $40 \mathrm{~min}$ by $4 \mathrm{ml}$ chloroform. After an additional $30 \mathrm{~min}$, the extract was centrifuged and the residue was re-extracted with $4 \mathrm{ml}$ 


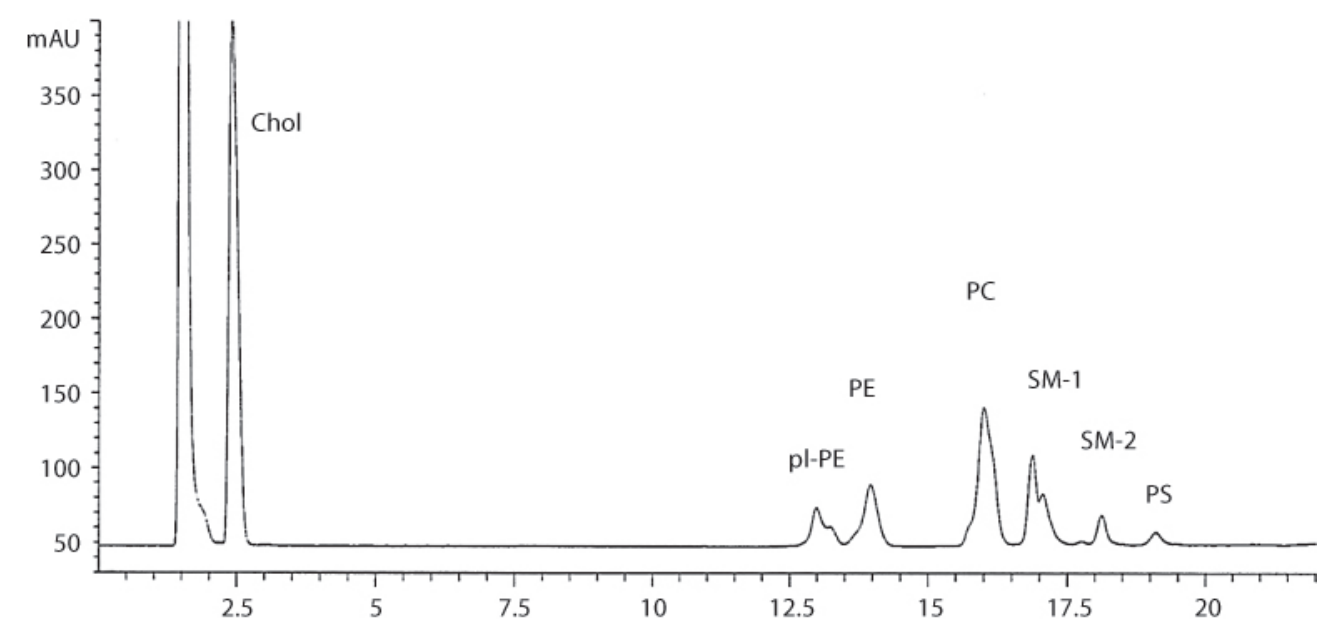

Fig. 1. Representative HPLC chromatogram of human erythrocyte lipids. Lipids were detected with an evaporative light-scattering detector. SM showed several peaks by this HPLC method, and two of the large peaks are tentatively named SM-1 and SM-2. Chol $=$ Cholesterol.

of methanol/chloroform $(1: 1, \mathrm{v} / \mathrm{v})$. Methanol and chloroform used in the extraction of lipids contained butylhydroxytoluene $(50 \mathrm{mg} / \mathrm{l})$. Pooled extracts were washed with $10 \mathrm{ml}$ of $50 \mathrm{~mm}$ $\mathrm{KCl}$ to make a biphasic mixture. One milliliter of the lower phase of the lipid extract was dried under N2 gas.

Separation of phospholipid classes including plasmalogens by HPLC was done by our reported method $[6,13]$. The HPLC system used was an Agilent HPLC system (Agilent Technologies, Tokyo, Japan) equipped with an evaporative light-scattering detector. The system was connected to a Chem Station (Agilent Technology) for control and analysis of chromatograms. The dried total lipids were dissolved in $200 \mu \mathrm{l}$ hexane/2-propanol $(1: 1, \mathrm{v} / \mathrm{v})$ and, after filtration through a $0.2-\mu \mathrm{m}$ filter, $20 \mu \mathrm{l}$ was injected into the HPLC system.

\section{Statistical Analysis}

We analyzed the data using a paired t test (two-tailed) with $\mathrm{p}<0.05$ used for significance.

\section{Results}

Erythrocyte membrane phospholipid classes including pl-PE and cholesterol was simultaneously detected by a single run of the HPLC (fig. 1). Relative composition of phospholipid classes was calculated on the basis of each chromatographic area, and then the ratios of glycerophosphospholipids to sphingomyelin (SM) were calculated (table 2). The ratio of pl-PE to $\mathrm{SM}$ decreased in $\mathrm{AD}$ as compared to the control group (table 2). The ratio of phosphatidylethanolamine (PE) and phosphatidylserine (PS) to SM also decreased. The ratio of phosphatidylcholine (PC) to SM was not changed. 
Table 2. Ratios of glycerophospholipids to sphingomyelin
Oma et al.: Changes in Phospholipid Composition of Erythrocyte Membrane in Alzheimer's Disease

\begin{tabular}{lcc}
\hline & Control $(\mathrm{n}=15)$ & $\mathrm{AD}(\mathrm{n}=16)$ \\
\hline $\mathrm{pl-PE} / \mathrm{SM}(\times 100)$ & $40.0 \pm 3.6$ & $35.2 \pm 3.6^{* * *}$ \\
$\mathrm{PE} / \mathrm{SM}(\times 100)$ & $50.4 \pm 7.6$ & $45.1 \pm 6.5^{*}$ \\
$\mathrm{PS} / \mathrm{SM}(\times 100)$ & $14.6 \pm 6.9$ & $8.5 \pm 7.1^{* *}$ \\
$\mathrm{PC} / \mathrm{SM}(\times 100)$ & $110.0 \pm 17.6$ & $102.4 \pm 10.4$ \\
\hline \multicolumn{2}{|l}{ Values are means $\pm \mathrm{SD} .{ }^{*} \mathrm{p}<0.05 ;{ }^{* *} \mathrm{p}<0.01 ;{ }^{* * *} \mathrm{p}<0.001 \mathrm{vs.}$} \\
control.
\end{tabular}

\section{Discussion}

Circulating human erythrocytes have no intracellular organelle, hence, lipids are present only in the plasma membrane. Therefore, the lipids extracted from the washed erythrocytes indicate the lipids of the erythrocyte membrane. SM in the human erythrocyte membrane contains few polyunsaturated fatty acids (PUFAs); on the other hand, PS contains a high amount of docosahexaenoic and arachidonic acid $[13,14]$. In the human erythrocyte membrane, PS contains a higher amount of PUFA than PE, and PC contains a much lower amount of PUFA than PS and PE $[13,14]$. It is known that phospholipids containing a high amount of PUFA are prone to oxidative stress $[15,16]$. Actually, our previous reports showed that relative composition of SM and PC increased in contrast to PS, PE, and pl-PE, when human erythrocytes were incubated with tert-butyl hydroperoxide (tBHP) [6]. Therefore, the ratio of each glycerophospholipid to $\mathrm{SM}$ is a good indicator of the degree of peroxidative change of each glycerophospholipid [6, 14].

Human erythrocyte pl-PE was composed of a higher amount of PUFA than PS and PE in our previous study [13], and actually the decrease of pl-PE in human erythrocytes due to oxidation with tBHP was about twice as much as that of PE and PS [6]. In the present study, degree of decrease of pl-PE was the highest among glycerophospholipids and, degree of decrease of PS was higher than that of PE (table 2). PC was not decreased. These results were very similar to the results of oxidation of human erythrocytes with tBHP [6]. Hence, the changes in the erythrocyte phospholipids in $\mathrm{AD}$ seem to reflect the changes by oxidative stress.

Many of the reports on possible peripheral biomarkers for AD indicated the presence of high oxidative stress in serum and erythrocytes of AD patients [10,17-21]; however, the source of oxidative stress in serum and erythrocytes is not necessarily clear. The presence of abnormal amyloid $\beta$-peptide in the blood of AD patients has been reported [22-24], and the interactions of amyloid $\beta$-peptide with erythrocytes have been indicated in $\mathrm{AD}$ [25-28]. Jayakumar et al. [25] reported that incubation of amyloid $\beta$-peptide with human erythrocytes resulted in binding of amyloid $\beta$-peptide to erythrocytes and that the process oxidized the erythrocytes. Nakagawa et al. [28] recently reported that both the incubation of human erythrocytes with amyloid $\beta$-peptide and the injection of amyloid $\beta$-peptide in mice resulted in binding of amyloid $\beta$-peptide to the erythrocytes and that both experiments induced peroxidation of erythrocyte phospholipids. Hence, amyloid $\beta$-peptide may be a source of oxidative stress in the blood of $\mathrm{AD}$ patients.

The present results showed an abnormal phospholipid composition of erythrocyte membranes in the $\mathrm{AD}$ group, indicating the presence of high oxidative stress in the circulating blood as compared to the age-matched non-demented group. 


\section{Acknowledgement}

We would like to thank Seibin Chen and Yuko Terasaki for their technical assistance.

\section{References}

-1 Ginsberg L, Rafique S, Xuereb JH, Rapoport SI, Gershfeld NL: Disease and anatomic specificity of ethanolamine plasmalogen deficiency in Alzheimer's disease brain. Brain Res 1995;698:223-226.

-2 Guan Z, Wang Y, Cairns NJ, Lantos PL, Dallner G, Sindelar PJ: Decrease and structural modifications of phosphatidylethanolamine plasmalogen in the brain with Alzheimer disease. J Neuropathol Exp Neurol 1999;58:740-747.

-3 Han X, Holtzman DM, Mckeel DW Jr: Plasmalogen deficiency in early Alzheimer's disease subjects and in animal models; molecular characterization using electrospray ionization mass spectrometry. J Neurochem 2001;77:1168-1180.

-4 Goodenowe DB, Cook LL, Liu J, Lu Y, Jayasinghe DA, Ahiahonu PW, Heath D, Yamazaki Y, Flax J, Krenitsky KF, Sparks DL, Lerner A, Friedland RP, Kudo T, Kamino K, Morihara T, Takeda M, Wood PL: Peripheral ethanolamine plasmalogen deficiency: a logical causative factor in Alzheimer's disease and dementia. J Lipid Res 2007;48:2485-2498.

-5 Wood PL, Mankidy R, Ritchie S, Heath D, Wood JA, Flax J, Goodenowe DB: Circulating plasmalogen levels and Alzheimer disease assessment scale-cognitive scores in Alzheimer patients. J Psychiatry Neurosci 2010;35:59-62.

-6 Mawatari S, Okuma Y, Fujino T: Separation of intact plasmalogens and all other phospholipids by a single run of high-performance liquid chromatography. Anal Biochem 2007;370:54-59.

-7 Bosman GJ, Bartholomeus IG, De Man AJ, Van Karmthout PJ, De Grip WJ: Erythrocyte membrane characteristics indicate abnormal cellular aging in patients with Alzheimer's disease. Neurobiol Aging 1991;12:13-18.

8 Janoshazi A, Sellal F, Marescaux C, Danion JM, Warter JM, Bary JD: Alteration of protein kinase C conformation: a potential marker for Alzheimer's disease but not for Parkinson's disease. Neurobiol Aging 2006;27:245-251.

-9 Kay MM, Goodman J: Brain and erythrocyte anion transporter protein, band 3, as a marker for Alzheimer's disease: structural changes detected by electron microscopy, phosphorylation, and antibodies. Gerontology 1997;43:44-66.

-10 Skoumalova A, Ivica J, Santrova P, Topinkova E, Wilhelm J: The lipid peroxidation products as possible markers of Alzheimer's disease in blood. Exp Gerontol 2011;46:38-42.

-11 Walter H, Widen KE, Read SL: Red blood cells from Alzheimer patients and from normal subjects discerned by cell electrophoresis in an aqueous polymer solution. Biochem Biophys Res Comm 1993; 194:23-28.

-12 Dise CA, Goodman DB, Rasmussen H: Definition of the pathway for membrane phospholipid fatty acid turnover in human erythrocytes. J Lipid Res 1980;21:292-300.

-13 Mawatari S, Yunoki K, Sugiyama M, Fujino T: Simultaneous preparation of purified plasmalogens and sphingomyelin in human erythrocytes with phospholipase A1 from Aspergillus orizae. Biosci Biotechnol Biochem 2009;73:2621-2625.

-14 Mawatari S, Murakami K: Analysis of membrane phospholipid peroxidation by isocratic high-performance liquid chromatography with ultraviolet detection. Anal Biochem 1998;264:118-123.

15 Clemens MR, Waller HD: Lipid peroxidation in erythrocytes. Chem Phys Lipids 1987;45:251-268.

-16 Wagner BA, Buetiner GR, Burns CP: Free radical-mediated lipid peroxidation in cells: oxidizability is a function of cell lipid bis-allylic hydrogen content. Biochemistry 1994;33:4449-4453.

-17 Baldeiras I, Santana I, Proenca MT, Garrucho MH, Pascoal R, Rodrigues A, Duro D, Oliveira CR: Peripheral oxidative damage in mild cognitive impairment and mild Alzheimer's disease. J Alzheimers Dis 2008;15:117-128.

18 Guidi I, Galimberti D, Lonali S, Novembrino C, Bamonti F, Tiriticco M, Fenoglio C, Venturelli E, Baron P, Bresolin N, Scarpini E: Oxidative imbalance in patients with mild cognitive impairment and Alzheimer's disease. Neurobiol Aging 2006;27:262-269. 
19 Gustaw-Rothenberg K, Kowalczuk K, Stryiecka-Zimmer M: Lipids' peroxidation markers in Alzheimer's disease and vascular dementia. Geriatr Gerontol Int 2010;10:161-166.

-20 Padurariu M, Ciobica A, Hritcu L, Stoica B, Bild W, Stefanescu C: Changes of some oxidative stress markers in the serum of patients with mild cognitive impairment and Alzheimer's disease. Neurosci Lett 2010;469:6-10.

-21 Torres LL, Quaglio NB, De Souza GT, Garcia RT, Dati LM, Moreira WL, Loureiro AP, De SouzaTararico JN, Smid J, Porto CS, Bottino CM, Nitrini R, Barros SB, Camarini R, Marcourakis T: Peripheral oxidative stress biomarkers in mild cognitive impairment and Alzheimer's disease. J Alzheimers Dis 2011;26:59-68.

-22 Blasko I, Jellinger K, Kemmler G, Krampla W, Jungwirth S, Wichart I, Tragl KH, Fischer P: Conversion from cognitive health to mild cognitive impairment and Alzheimer's disease: prediction by plasma amyloid beta 42, medial temporal lobe atrophy and homocysteine. Neurobiol Aging 2008;29: $1-11$.

-23 Cammarata S, Borghi R, Giliberto L, Pardini M, Pollero V, Novello C, Fornaro M, Vitali A, Bracco L, Caltagirone C, Bossu P, Odetti P, Tabaton M: Amyloid-beta42 plasma levels are elevated in amnestic mild cognitive impairment. J Alzheimers Dis 2009;18:267-271.

-24 Schupf N, Tang MX, Fukuyama H, Manly J, Andrews H, Mehta P, Ravetch J, Mayeux R: Peripheral Abeta subspecies as risk biomarkers of Alzheimer's disease. Proc Natl Acad Sci USA 2008;105:1405214057.

-25 Jayakumar R, Kusiak JW, Chrest FJ, Demehin AA, Murali J, Wersto RP, Nagabubu E, Ravi L, Rifkind JM: Red cell perturbations by amyloid beta-protein. Biochim Biophys Acta 2003;1622:20-28.

-26 Kuo YM, Kokjohn TA, Kalback W, Luehrs D, Galasko DR, Chevallier N, Koo EH, Emmerling MR, Roher AE: Amyloid-beta peptides interact with plasma proteins and erythrocytes: implications for their quantification in plasma. Biochem Biophys Res Comm 2000;268:750-756.

-27 Mattson MP, Begley JG, Mark RJ, Furukawa K: A $325-35$ induces rapid lysis of red blood cells: contrast with A $\beta 1-42$ and examination of underlying mechanisms. Brain Res 1997;771:147-153.

-28 Nakagawa K, Kiko T, Miyazawa T, Sookwong P, Tsuduki T, Satoh A, Miyazawa T: Amyloid $\beta$-induced erythrocytic damage and its attenuation by carotenoids. FEBS Lett 2011;585:1249-1254. 